\title{
Survival and growth of the forage grass Festuca rubra in naturally and artificially devegetated sites in a sub-arctic coastal marsh
}

Post-print/Accepted manuscript

Pamela C. O

Peter M. Kotanen

Kenneth F. Abraham

Pamela C. O, Peter M. Kotanen \& Kenneth F. Abraham (2005) Survival and growth of the forage grass Festuca rubra in naturally and artificially devegetated sites in a sub-arctic coastal marsh, Écoscience, 12:2, 279-285 doi: 10.2980/i1195-6860-12-2-279.1

The Version of Record of this manuscript has been published and is available in Écoscience 12 (2005) http://www.tandfonline.com/doi/abs/10.2980/i1195-6860-12-2-279.1

\section{HOW TO CITE TSPACE ITEMS}

Always cite the published version, so the author(s) will receive recognition through services that track citation counts, e.g. Scopus. If you need to cite the page number of the TSpace version (original manuscript or accepted manuscript) because you cannot access the published version, then cite the TSpace version in addition to the published version using the permanent URI (handle) found on the record page. 


\title{
Survival and growth of the forage grass, Festuca rubra, in naturally and
}

\section{artificially devegetated sites in a sub-arctic coastal marsh}

\author{
Pamela C. $\mathbf{O}^{1,2}$
}

Department of Botany, University of Toronto, 3349 Mississauga Road North, Mississauga, Ontario, L5L 1C6, CANADA

\section{Peter M. KOTANEN}

Department of Botany, University of Toronto, 3349 Mississauga Road North, Mississauga, Ontario, L5L 1C6, CANADA

\section{Kenneth F. ABRAHAM}

Ontario Ministry of Natural Resources, 300 Water Street, Peterborough, Ontario, K9J 8M5,

\section{CANADA}

${ }^{1}$ Pamela C. O, Department of Geography, University of British Columbia, 1984 West Mall, Vancouver, British Columbia, V6T 1Z2, CANADA.

${ }^{2}$ Correspondence author: e-mail: po@utm.utoronto.ca, Tel: (604) 822-3441, FAX: (604) 822-6150 


\section{Abstract}

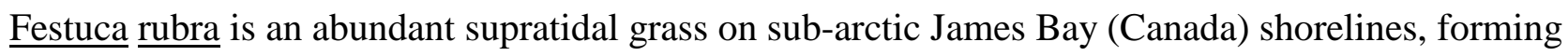
extensive near-monocultures that are used as forage by nesting and migrating geese. Studies at other, more northern North American locations have shown grubbing by geese can have severe consequences for intertidal and supratidal marshes, but this research has focussed on plant communities that differ substantially in species composition, physical environment, and extent from James Bay's Festuca meadows. In this study, we examined the responses of this grass to natural and simulated goose grubbing in Festuca swards heavily used by Lesser Snow Geese, Canada Geese, and Brant at Akimiski Island in James Bay. We transplanted Festuca into plots previously devegetated by geese, into plots where we removed vegetation to simulate goose grubbing, and into intact vegetation (controls). We found shoots transplanted into control and artificially grubbed plots survived well, but those transplanted into previously devegetated areas usually died. Growth initially was reduced in naturally devegetated sites, but the few survivors in the following year performed as well as plants transplanted into intact or artificially grubbed sites. Spot measurements suggested that naturally devegetated sites suffered from degraded soil conditions, such as hypersalinity and increased temperature. These results provide evidence that recovery of Festuca swards following loss of vegetation is likely to be difficult, probably as a result of deteriorating soil conditions. Models of goose-plant interactions developed at substantially more northern sites thus seem applicable to the significantly different plant communities of the James Bay shoreline.

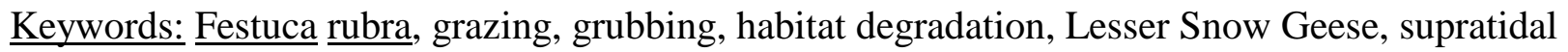
marsh

Nomenclature: Plants - Blaney \& Kotanen 2001; Birds - AOU (1998) Check-list of North American Birds (7th edition) 


\section{Introduction}

Natural disturbance helps to maintain many ecosystems (Sousa 1984; Pickett \& White 1985); for example, fires often significantly contribute to the structure and dynamics of forests, savannas, and grasslands (e.g., Boyd \& Bidwell 2002; Odion \& Davis 2000; Morgan \& Lunt 1999). In contrast, disturbance also can lead to the loss or degradation of ecosystems. Many of the most severe examples of disturbance result directly or indirectly from human activities such as agriculture, industry, and forestry (Lindenmayer \& McCarthy 2002, Jefferies 1997). The impacts of such disturbances may be far removed from their source of origin. A good example is the effect of tropical deforestation, which reduces northern temperate and boreal migratory bird populations by reducing their wintering habitats (Finch and Stangel 1993).

Populations of Lesser and Greater Snow Geese (Chen caerulescens caerulescens, $\underline{\text { C. }} \underline{\text { c. }}$

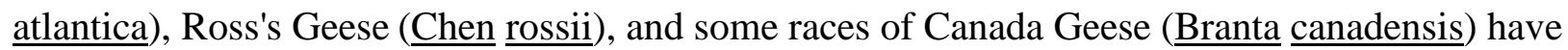
increased in recent decades as a result of agriculture on their overwintering grounds, reduced hunting harvest rates along their migratory pathways, and the creation of wildlife refuges in the United States (Abraham et al. 1996; Abraham \& Jefferies 1997; Jefferies 1997; Miller et al. 1998; Jefferies et $\underline{\text { al. } 2004 a, b, c) . ~ I n ~ s o m e ~ c a s e s, ~ t h e s e ~ i n c r e a s i n g ~ p o p u l a t i o n s ~ a r e ~ h a v i n g ~ a ~ n e g a t i v e ~ i m p a c t ~}$ on northern staging and breeding areas thousands of kilometers away from the anthropogenic causes of their growth (Jefferies \& Rockwell 2002; Jefferies et al. 2004a,b,c). Lesser Snow Geese of the mid-continent population are a good example because of their rapid rates of increase (Rockwell et al. 1997) and destructive foraging methods (Jefferies \& Rockwell 2002; Jefferies et al. 2004b). These geese graze above-ground parts of plants during the post-hatch period beginning in mid-June (Abraham \& Jefferies 1997); at moderate intensities, this grazing can be sustainable (Cargill \& Jefferies 1984; Bazely \& Jefferies 1985; Hik et al. 1991). In contrast, in spring and fall, they 
destructively grub below-ground plant parts (Jefferies et al. 1979; Jefferies et al. 2004b). As goose populations have expanded, the intensity of grazing and grubbing has increased, resulting in loss of vegetation on their arctic breeding grounds (Abraham \& Jefferies 1997) and changes in exposed soil such as increased salinity and temperature (Iacobelli \& Jefferies 1991; Srivastava \& Jefferies 1996; McLaren \& Jefferies 2004).

Damage by Lesser Snow Geese to northern plant communities is believed to occur in a series of steps (Jefferies 1997; Abraham \& Jefferies 1997; Jefferies \& Rockwell 2002; Jefferies et al. 2004b). First, heavy grazing of intertidal saltwater marshes converts their preferred forage,

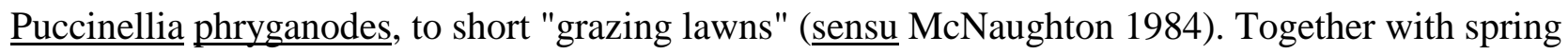
grubbing, excessive grazing eventually converts these lawns to unvegetated mudflats. The geese next utilize supratidal saline and brackish marshes for forage. These marshes undergo similar damage to intertidal marshes, with intact vegetation replaced by grazing lawns and ultimately mudflats. Geese also increasingly exploit inland freshwater marshes (Kerbes et al. 1990; Kotanen and Jefferies 1997), depleting the forage species in heavily used areas. This pattern of moving further inland from intertidal to supratidal to freshwater marshes has been observed at multiple sites, including La Pérouse Bay, Manitoba, the west coast of Hudson Bay, and the north shore of Akimiski Island in James Bay.

Although consequences of intense foraging by geese have been well documented for arctic intertidal marshes, and to a lesser extent, for freshwater sedge meadows, almost all the work in northern supratidal sites has been conducted at La Pérouse Bay in habitats very different from those at Akimiski Island (Jefferies et $\underline{\text { al. } 2004 b) . ~ T h e ~ s u p r a t i d a l ~ a t ~ L a ~ P e ́ r o u s e ~ B a y ~ i s ~ a ~ v e r y ~ h e t e r o g e n e o u s ~}$ mixture of Puccinellia phryganodes / Carex subspathacea grazing flats, salt pans, and willows;

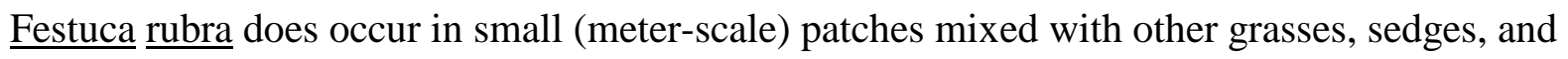


dicots, but never forms the extensive (100m to km-scale) near-monocultures that dominate supratidal sites on James Bay. Although Snow Geese at La Pérouse Bay use Festuca as a nonpreferred food (Hik et al. 1992; Gadallah and Jefferies 1995a,b), it is a minor source of forage compared to both intertidal Puccinellia flats and freshwater sedgelands. In contrast, at Akimiski, Festuca meadows rapidly are replacing the intertidal as the principal source of forage for Snow Geese near their colony, as the intertidal flats are progressively devegetated, and also are a preferred foraging habitat for Canada Geese. Finally, although numerous studies in temperate Europe have considered interactions between Festuca rubra and foraging geese (e.g., van der Wal et al. 1998; Dormann et al. 2000; Bos et al. 2002), these systems significantly differ from ours in climate, herbivore species (different goose species, as well as brown hares and livestock), plant communities (additional important competitors, notably Phragmites), and management (most are in managed systems with ongoing or historical agriculture), and have focussed on grazing rather than grubbing. Thus, our studies of Festuca meadows are necessary both because they extend the current model of goose-plant interactions to a major new North American habitat type, and because this habitat represents a key future source of forage for nesting birds.

Our research used experimental transplants to assess whether survival and growth of the dominant supratidal grass, Festuca rubra L., are possible in areas where loss of Festuca-dominated vegetation previously has occurred. We also attempted to determine if areas completely devegetated by geese in previous years are harder to revegetate than freshly disturbed sites. Comparing artificially grubbed sites with ungrubbed controls allowed us to test the immediate effects of devegetation on the survival and performance of Festuca in a fully randomized, replicated, controlled experiment. Comparing these treatments with areas naturally devegetated in previous years allowed us to investigate whether these short-term effects changed over time. Our hypotheses 
were: 1) devegetation should result in an immediate decrease in the survival and growth of transplanted Festuca; and 2) the negative effects of devegetation on growth and survival should increase over time.

\section{Materials and Methods}

\section{$\underline{\text { Study Site }}$}

Akimiski Island, Nunavut Territory, Canada $\left(53^{\circ} \mathrm{N}, 81^{\circ} \mathrm{W}\right)$ is the largest island in James Bay, which lies at the southernmost end of Hudson Bay. This $3800 \mathrm{~km}^{2}$ island is located just offshore of the community of Attawapiskat, Ontario, and is roughly $1000 \mathrm{~km}$ to the southeast of the well-known Snow Goose colony at La Pérouse Bay, Manitoba $\left(58^{\circ} \mathrm{N}^{\prime}, 94^{\circ} \mathrm{W}\right)$. Three species of geese nest, stage, or molt on the island in significant numbers: Lesser Snow Geese, Canada Geese, and Brant (Branta bernicla hrota). Currently, up to 2,000 pairs of Lesser Snow Geese nest in a $20 \mathrm{~km}$ stretch along the north shore of the island (Abraham et al. 1999). An average of 9,947 breeding pairs of Canada Geese (‥ $\underline{\text { c. }} \underline{\text { interior) }}$ nested throughout the island between 1990-2001 (Mississippi Flyway Technical Section 2003) with about $20 \%$ of the nests located on the north shore. Molt-migrant giant Canada Geese (․․ $\underline{\text { c. maxima) }}$ ) using the island have increased in numbers since the 1970s (Leafloor

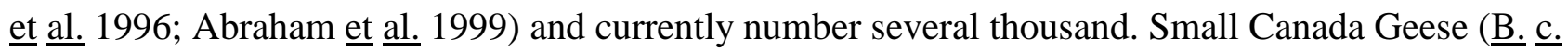
hutchinsii) occur on the island during fall migration (Thomas \& Prevett 1982), but their current numbers are unknown. During spring migration, Brant stage for approximately one month, and single day counts of 10,000 individuals have been recorded; these geese graze intensively in the early growing season, but do not grub vegetation. Habitat damage on the north coast of Akimiski Island is most evident in areas where both Lesser Snow and Canada Geese nest, and in areas used for staging by Brant and Giant Canada Geese as well as by broods of both Lesser Snow and Canada Geese. 
This experiment was conducted on the north shore of Akimiski Island in the supratidal marshes along a small river (unofficially called the "Thompson River": 53 $11^{\prime} \mathrm{N}, 81^{\circ} 26^{\prime} \mathrm{W}$ ), in an area where both Lesser Snow Geese and Canada Geese nest. Supratidal vegetation is dominated by

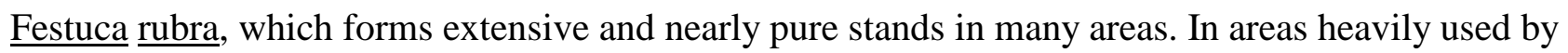
geese, a mosaic of taller Festuca stands (ca. $15 \mathrm{~cm})$, shorter grazing lawns $(\leq 2 \mathrm{~cm})$, and bare (formerly vegetated) plateaus has been created. Minor species co-occurring with $\underline{\text { Festuca include }}$

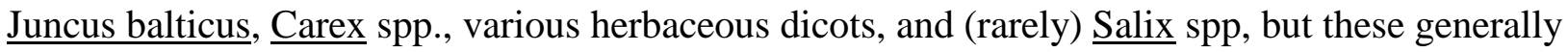
contribute $<1 \%$ of biomass in the Festuca pastures that formed the focus of this study.

\section{Experimental Design}

Sixty $1 \mathrm{~m}$ x $1 \mathrm{~m}$ experimental plots were established in June 2001. Forty of these plots were placed in short Festuca grazing lawns. Twenty were interspersed in unvegetated soils which had lost their plant cover as a result of goose grubbing in years prior to this study (conservatively, a minimum of 2 years earlier); cover in these areas is believed originally to have been dominated by $\underline{\text { Festuca, }}$ based on remnant vegetation, tidal position, and frequency of inundation. Within each $1 \mathrm{~m}$ x 1m plot, two circular subplots of $30 \mathrm{~cm}$ diameter $\left(707 \mathrm{~cm}^{2}\right.$ in area) were created, one for destructive biomass sampling on 1-2 August 2001 and one for 7-8 July 2002; research in arctic salt marshes has shown this size of subplot to be sufficient to significantly affect revegetation and soil processes (McLaren \& Jefferies 2004). Both subplots in half of the grazing lawn plots were then grubbed by hand. Goose grubbing was simulated by using a knife to remove vegetation from each circle and hand-pulling any remaining shoots. The end result was a total of three treatments, each with 20 replicate plots: 1) artificial grubbing, 2) natural devegetation, and 3) intact grazing lawn controls. All subplots received five transplants of $2 \mathrm{~cm} \mathrm{x} 3 \mathrm{~cm}$ x $1.5 \mathrm{~cm}$ deep plugs of Festuca collected locally from grazing lawns. This is a highly clonal plant; we assume each of these small 
plugs likely represented a fragment of a single genet. How (or if) Festuca naturally establishes in devegetated areas is unknown, but regeneration from seed, fragments, and surviving plants are possibilities; this experiment was intended to assess the suitability of disturbed habitats for Festuca, rather than directly imitating the natural revegetation process. Finally, each plot was enclosed in a chicken wire cage to protect the transplants from damage by geese; this was necessary since this experiment was designed to determine whether Festuca potentially is able to establish in damaged sites, not whether geese currently can prevent this establishment. Sampling and Analysis

Biomass and plant status (alive or dead) were determined on 1-2 August 2001 and 7-8 July 2002. Transplants were judged to be dead if they contained no living shoots. The above-ground parts of each surviving transplant were collected and sorted into live and dead material; values of the five transplants per subplot were averaged before analysis. These weights are reported as grams per transplant, since the area covered by each transplant was too small to measure accurately. In addition, any naturally occurring plants, including colonists of Festuca or other species, were collected from one quarter of the $30 \mathrm{~cm}$ diameter sampling area $\left(177 \mathrm{~cm}^{2}\right)$ and weighed separately. These values have been extrapolated to grams per square meter, to facilitate comparison with other studies.

Spot measures of several physical parameters also were made; these were intended to provide a snapshot of physical conditions, rather than a detailed description. Soil salinity, temperature, and water content were measured on 1-2 August 2001 and 7-8 July 2002. Soil salinity was measured with the standard saturated soil-paste method using a conductivity meter (Rhoades 1996). Daytime soil temperatures were measured using a Barnant 115 Thermocouple Thermometer, placing the probe $2.5 \mathrm{~cm}$ into the soil. In order to determine percent water content, soil was 
collected, weighed, and placed in a drying oven at 50 - $70 \mathrm{C}$ until completely dry, and weighed again.

The number of surviving transplants on each sampling date was analyzed with KruskalWallis tests because the data were highly non-normal. Significant tests were followed with nonparametric post-hoc analyses (Bonferroni-corrected Mann-Whitney U-tests with familywise $\alpha=$ 0.05). All other data were analyzed using one-way analysis of variance (ANOVA) followed by posthoc Tukey-Kramer analyses with familywise $\alpha=0.05$ when ANOVA results were significant. This approach was adopted after split-plot analyses demonstrated that treatment effects differed significantly between years (treatment $\mathrm{x}$ year interaction: $\mathrm{p}<0.05$ ); one-way analyses also solved problems resulting from missing data and differences in variance between years. In addition, salinity was log-transformed before analysis to improve homogeneity of variance; proportional data were arcsine-square root transformed before analysis. Bonferroni correction did not alter patterns of significance for the principal (biomass and survival) variables measured; thus, uncorrected overall ANOVA and Mann-Whitney results are presented. Degrees of freedom varied based on the number of samples successfully recovered for each sample period. Means are reported \pm 1 standard error.

\section{Results}

\section{$\underline{\text { Survival of Transplants }}$}

Kruskal-Wallis tests demonstrated highly significant differences among treatments in the survival of transplants for both $2001(\mathrm{H}=27.76, \underline{\mathrm{df}}=2, \mathrm{p}<0.0001)$ and $2002(\mathrm{H}=22.91, \underline{\mathrm{df}}=2$, $\mathrm{p}<0.0001)$. Survival of transplants in intact vegetation and artificially grubbed plots was similar and relatively high, while the survival of transplants in naturally devegetated plots consistently was very low (Figure 1a). Post-hoc comparisons confirmed that survival in naturally devegetated plots differed significantly from survival in the other two treatments (Figure 1a). 


\section{Above-ground Biomass of Transplants}

The live above-ground biomass of surviving transplants differed among treatments in 2001 $\left(\mathrm{F}_{2,57}=37.42, \mathrm{p}=0.0001\right)$ but not in $2002\left(\mathrm{~F}_{2,41}=2.34, \mathrm{p}=0.109\right)$. Post-hoc analyses of data from 2001 found that artificially grubbed plots and the intact plots had significantly higher live biomass than the naturally devegetated treatment (Figure 1b). The non-significant differences between treatments in 2002 could be due to a small sample size for surviving transplants in naturally devegetated plots $(n=5)$.

Dead biomass indicates how much tissue has senesced before sampling, and can indicate whether a plant is suffering increased rates of tissue death. There were significant treatment effects on dead biomass of surviving transplants in $2001\left(\mathrm{~F}_{2,57}=14.40, \mathrm{p}=0.0001\right)$ and $2002\left(\mathrm{~F}_{2,41}=9.40\right.$, $\mathrm{p}=0.0004$ ). Post-hoc comparisons for 2001 found that transplants in intact vegetation had the highest amount of dead biomass, transplants in artificially grubbed plots had intermediate values, and transplants in naturally devegetated areas had the lowest values (Figure 1c). In 2002, transplants in intact vegetation again had significantly higher amounts of dead biomass than transplants in artificially grubbed plots or naturally devegetated areas (Figure 1c).

The proportion of above-ground biomass that is alive (= live biomass / [live + dead biomass]) is an indicator of plant vitality, and can indicate whether growth exceeds senescence or

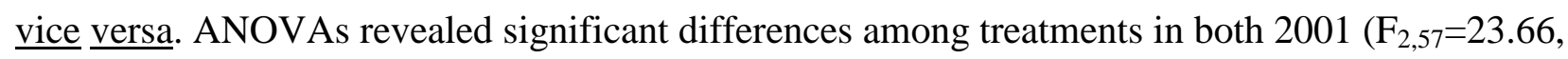
$\mathrm{p}=0.0001)$ and $2002\left(\mathrm{~F}_{2,41}=38.36, \mathrm{p}=0.0001\right)$. In 2001, post-hoc comparisons found that transplants in naturally devegetated areas had a lower proportion of live Festuca biomass $(0.35 \pm 0.77)$ than plants in either the artificially grubbed plots $(0.81 \pm 0.24)$ or in intact vegetation $(0.75 \pm 0.03)$. In 2002, all treatments were significantly different from each other; the naturally devegetated 
treatments had the highest proportion of live material $(0.75 \pm 0.02)$, the artificially grubbed plots had intermediate values $(0.63 \pm 0.02)$, and the intact vegetation had the lowest proportion $(0.52 \pm 0.02)$.

Biomass of naturally occurring vegetation within experimental plots, sampled only in 2002, also differed among treatments $\left(\mathrm{F}_{2,27}=155.17, \mathrm{p}<0.0001\right)$. Plots of intact vegetation had the greatest amounts of naturally occurring Festuca biomass $\left(129.94 \pm 9.45 \mathrm{gm}^{-2}\right)$; non-transplant $\underline{\text { Festuca }}$ biomass in naturally devegetated $\left(0.01 \pm 0.01 \mathrm{gm}^{-2}\right)$ and artificially grubbed $\left(8.72 \pm 3.57 \mathrm{gm}^{-2}\right)$

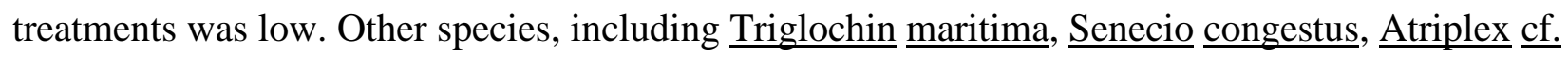

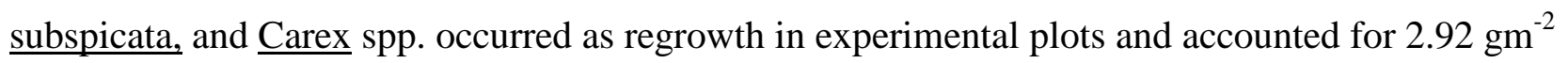
in undamaged sites, $4.11 \mathrm{gm}^{-2}$ in artificially grubbed plots, and $0.60 \mathrm{gm}^{-2}$ in naturally devegetated areas; these numbers amount to less than $4 \%$ of the biomass of Festuca in undisturbed sites. Environmental factors

Our environmental measurements are based on a very small number of sampling episodes. Such infrequent samples are not able to provide a detailed description of physical conditions in degraded and intact sites, nor was that the intent. Instead, we present them as point samples of overall trends. They should not be interpreted as direct evidence that the physical conditions described are necessarily the cause of patterns in growth and survival of Festuca.

Soil salinity differed significantly among treatments in August $2001\left(\mathrm{~F}_{2,15}=14.19\right.$, $\mathrm{p}=0.0003)$ : post-hoc tests found that naturally devegetated sites $\left(1.48 \pm 0.75 \mathrm{gL}^{-1}\right)$ were significantly more saline than either intact vegetation $\left(0.13 \pm 0.02 \mathrm{gL}^{-1}\right)$ or artificially grubbed $\left(0.26 \pm 0.06 \mathrm{gL}^{-1}\right)$ treatments. Similarly, in July 2002, treatments differed significantly $\left(F_{2,15}=7.87, p=0.0046\right)$; in this case, post-hoc tests found that naturally devegetated soils $\left(4.68 \pm 1.41 \mathrm{gL}^{-1}\right)$ were more saline than intact sites $\left(1.15 \pm 0.16 \mathrm{gL}^{-1}\right)$, but artificially grubbed plots had intermediate salinity values that did not differ significantly from either of the other treatments $\left(2.03 \pm 0.49 \mathrm{gL}^{-1}\right)$. Soil moisture also 
differed between treatments on both sampling dates (2001: $F_{2,57}=3.48, p=0.038 ; 2002: F_{2,57}=6.19$, $\mathrm{p}=0.004)$. Post-hoc comparisons for 2001 revealed soil water content in the naturally devegetated areas (46.65 $\pm 1.91 \%)$ was significantly lower than in artificially grubbed plots (52.82 $\pm 1.73 \%)$, while intact vegetation (50.13 $\pm 1.27 \%$ ) did not differ from either treatment. In 2002, the naturally devegetated treatment (32.30 $\pm 1.70 \%)$ had lower soil moisture than both the intact vegetation

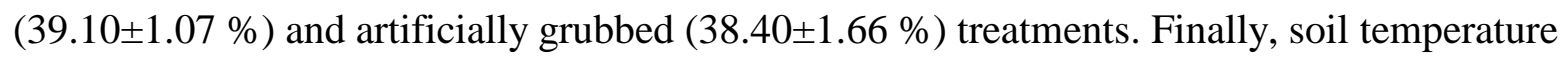
differed among treatments in August $2001\left(\mathrm{~F}_{2,57}=7.33, \mathrm{p}=0.002\right)$ and July $2002\left(\mathrm{~F}_{2,57}=14.51\right.$,

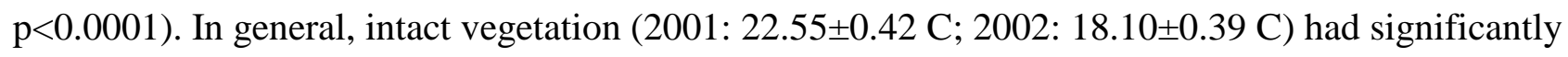
cooler soil temperatures than naturally devegetated (2001: $24.97 \pm 0.49 \mathrm{C} ; 2002: 21.59 \pm 0.47 \mathrm{C}$ ) or

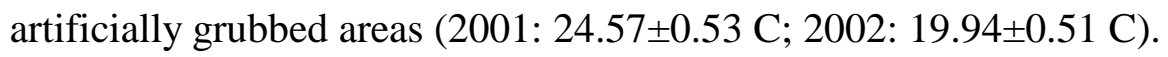

\section{Discussion}

Studies in intertidal and supratidal marshes of the sub-arctic/arctic boundary have shown that transplants of forage species often are unable to establish and survive in areas devegetated by Lesser Snow Geese; whether establishment is possible depends on the extent of soil degradation (Handa \& Jefferies 2000; Handa et al. 2002; McLaren \& Jefferies 2004). Similarly, we found that transplants of Festuca rubra survived well for two seasons in undisturbed control plots and in artificially grubbed plots, but their survival was greatly reduced in older, natural disturbance. These differences may reflect a greater degree of soil degradation in sites that have been devegetated longer, though this requires further study.

As revealed by patterns of live biomass, growth of surviving transplants also was initially better in controls and artificially grubbed plots than in naturally devegetated sites, but in the second year growth of the few surviving transplants in naturally devegetated sites was equal to that in the other treatments. These results must be treated with suspicion given the small sample size in 2002. 
However, they may in part reflect reduced levels of senescence in grubbed areas: plants in both naturally and artificially devegetated sites had lower levels of dead biomass than plants in intact vegetation in both 2001 and 2002. As well, the proportion of live biomass was reduced relative to intact plots in naturally degraded areas in 2001, but increased in 2002, suggesting senescence may have initially increased, but then declined. We suspect these results indicate that transplants into naturally devegetated areas suffered a severe dieback in the first year, but that those few individuals that did survive (possibly because of chance placement in favourable microsites) may have enjoyed reduced competition compared to plants in freshly disturbed areas and especially in intact swards. Once established, it also is possible that these plants may have gradually improved their own microenvironment, for example by aerating soil through root growth, or by trapping water and reducing salinity (Shumway and Bertness 1994), thereby creating "safety islands" (Urbanska 1997) for further growth and revegetation. It is uncertain whether the good performance of the survivors can persist, or whether these plants eventually succumb to adverse physical conditions, similarly to the majority of transplants in the naturally devegetated sites.

Our results suggest that re-establishment of Festuca in areas devegetated by geese is likely to be a slow process: not only was transplant survival poor in naturally devegetated areas, but we also observed little natural recolonization in this two-year study. Handa \& Jefferies (2000) also found natural establishment of Festuca rubra at La Pérouse Bay to be severely limited in degraded areas, though it was increased by presence of earlier successional vegetation consisting largely of intertidal species. It is possible that the re-establishment of Festuca at Akimiski Island similarly might benefit following colonization by other species, such as those that we recorded volunteering in our plots. Indeed, surviving plants of Festuca might themselves act as templates for further revegetation, especially if they ameliorate the environment as speculated above. 
Studies of the Snow Goose colony at La Pérouse Bay, Manitoba, suggest that the soil properties most likely to hinder revegetation of damaged areas include increased bulk density, increased anoxia, reduced water content, and hypersalinity (Iacobelli \& Jefferies 1991; Srivastava \& Jefferies 1996; Handa \& Jefferies 2000; McLaren \& Jefferies 2004). It takes time for these processes of soil damage to occur, so that the degradation of the soil worsens over time (Iacobelli \& Jefferies 1991; Srivastava \& Jefferies 1996; Handa \& Jefferies 2000; McLaren \& Jefferies 2004). This is consistent with our result that substantial transplant establishment was possible in freshly disturbed sites, but not in older naturally devegetated soils. Our spot estimates found that soil water content was lower in soil from naturally devegetated areas than in intact vegetation, and that salinity was higher in the naturally devegetated soils than any other treatment. Because these estimates are based on such a small number of samples, they cannot be assumed to be adequate descriptions of the physical environment; however, results from other degraded northern coastal marshes (Iacobelli \& Jefferies 1991; Srivastava \& Jefferies 1996; McLaren \& Jefferies 2004) nonetheless suggest these measurements might reflect conditions over much of the summer. Several of these factors potentially could underlie the reduced plant performance in degraded areas; further experimental work with Festuca in controlled conditions is required to identify the specific mechanisms involved.

\section{$\underline{\text { Conclusions }}$}

Contrary to our Hypothesis 1, devegetation did not result in an immediate decrease in the survival and growth of transplanted Festuca; however, as predicted by our Hypothesis 2, survival was much reduced in areas devegetated by geese in previous years (though the few survivors performed unexpectedly well), suggesting the effects of devegetation worsen over time. Our results suggest that devegetation of subarctic Festuca meadows by geese may be difficult to reverse, as has been documented in other habitats at La Pérouse Bay (Jefferies et al. 2004b). 
Thus, not only does our paper represent one of the first studies of grubbing by geese in this important coastal habitat, but it also provides independent support for goose-habitat models developed 1000 km away.

\section{Acknowledgments}

This research was supported by an NSERC (Canada) PGS-A and Northern Research Supplement, a Richard H.G. Bonnycastle Graduate Fellowship from the Institute for Wetlands and Waterfowl Research, and the NSTP program of the Department of Indian Affairs and Northern Development (PCO); an NSERC Discovery Grant (PMK); and the Ontario Ministry of Natural Resources (KFA). Thanks to Jim Leafloor for arranging logistical support, and to Bob Jefferies, Jackie Ngai, José Ramón Obeso, and two anonymous reviewers for improvements to the manuscript. Numerous members of the Akimiski Field Station provided lab and field assistance, particularly Steven Guenther, Sarah Hagey, and Tyler Muhly. This is a contribution of the Wildlife Research and Development Section of the Ontario Ministry of Natural Resources. 


\section{Literature cited}

Abraham, K.F., Jefferies, R.L., Rockwell, R.F. \& C.D. MacInnes, 1996. Why are there so many white geese in North America? Pages 79-92 in J.T. Ratti (ed.). Proceedings of the $7^{\text {th }}$ International Waterfowl Symposium, Memphis, Tennessee, 4-6 February 1996. Ducks Unlimited, Memphis, Tennessee.

Abraham, K.F. \& R.L. Jefferies, 1997. High goose populations: causes, impacts and implications. Pages 7-72 in B.D.J. Batt (ed.). Arctic Ecosystems in Peril: Report of the Arctic Goose Habitat Working Group. Arctic Goose Joint Venture. Canadian Wildlife Service and US Fish and Wildlife Service, Washington, D.C. (ISBN 0-9617279-3-4).

Abraham, K.F., Leafloor, J.O. \& H.G. Lumsden, 1999. Establishment and growth of Lesser Snow Goose (hen caerulescens $\underline{\text { caerulescens) }}$ nesting colony on Akimiski Island, James Bay, Northwest Territories. Canadian Field-Naturalist, 113: 245-250.

Bazely, D.R. \& R.L. Jefferies, 1985. Goose faeces: a source of nitrogen for plant growth in a grazed salt-marsh. Journal of Applied Ecology, 22: 693-703.

Blaney, C.S. \& P.M. Kotanen, 2001. The vascular flora of Akimiski Island, Nunavut Territory. The Canadian Field-Naturalist, 115: 88-98.

Bos, D., Bakker J.P., de Vries, Y. \& S. van Lieshout, 2002. Long-term vegetation changes in experimentally grazed and ungrazed back barrier marshes in the Wadden Sea. Applied Vegetation Science, 5: 45-54.

Boyd, C.S. \& T.G. Bidwell, 2002. Effects of prescribed fire in Shinnery Oak (Quercus harardii) plant communities in Western Oklahoma. Restoration Ecology, 10: 324-333.

Cargill, S.M. \& R.L. Jefferies, 1984. The effects of grazing by lesser snow geese on the vegetation of a sub-arctic salt marsh. Journal of Applied Ecology, 21: 669-686. 
Dormann, C.F., van der Wal, R. \& J.P. Bakker, 2000. Competition and herbivory during salt marsh succession: the importance of forb growth strategy. Journal of Ecology, 88: 571-583.

Finch, D.M. \& P.W. Stangel, 1993. Status and management of neotropical migratory birds. USDA Forest Service General Technical Report RM-229. Rocky Mountain Forest and Range Experiment Station, USDA Fort Collins, CO.

Gadallah, F.L. \& R.L. Jefferies, 1995a. Comparison of the nutrient contents of the principal forage plants utilized by lesser snow geese on summer breeding grounds. Journal of Applied Ecology, 32: $263-275$.

Gadallah, F.L. \& R.L. Jefferies, 1995b. Forage quality in brood rearing areas of the lesser snow goose and the growth of captive goslings. Journal of Applied Ecology, 32: 276-287.

Handa, I.T. \& R.L. Jefferies, 2000. Assisted revegetation trials in degraded salt marshes. Journal of Applied Ecology, 37: 944-958.

Handa, I.T., Harmsen, R. \& R.L. Jefferies, 2002. Patterns of vegetation change and the recovery potential of degraded areas in a coastal marsh system of the Hudson Bay lowlands. Journal of Ecology, 90: 86-99.

Hik, D.S., Sadul, H.A. \& R.L. Jefferies, 1991. Effects of the timing of multiple grazings by geese on net above-ground primary production of swards of Puccinellia phryganodes. Journal of Ecology, 79: 715-730.

Hik, D.S., Jefferies, R.L. \& A.R.E. Sinclair, 1992. Foraging by geese, isostatic uplift, and asymmetry in the development of salt-marsh plant communities. Journal of Ecology, 80: 395406.

Iacobelli, A. \& R.L. Jefferies, 1991. Inverse salinity gradients in coastal marshes and the death of $\underline{\text { Salix: }}$ the effects of grubbing by geese. Journal of Ecology, 79: 61-73. 
Jefferies, R.L., Jensen, A. \& K.F. Abraham, 1979. Vegetational development and the effect of geese on vegetation at La Pérouse Bay, Manitoba. Canadian Journal of Botany, 57: 1439-1450.

Jefferies, R.L., 1997. Long-term damage to sub-Arctic coastal ecosystems by geese: ecological indicators and measures of ecosystem dysfunction. Pages 151-165 in R.M.M. Crawford (ed.). Disturbance and Recovery in Arctic Lands. Kluwer Academic Publishers, Netherlands.

Jefferies, R.L. \& R.F. Rockwell, 2002. Foraging geese, vegetation loss and soil degradation in an Arctic salt marsh. Applied Vegetation Science, 5: 7-16.

Jefferies, R.L., Henry, H.A.L. \& K.F. Abraham, 2004a. Agricultural nutrient subsidies to migratory geese and change to Arctic coastal habitats. Pages 268-283 in G.A. Polis, M.E. Power, and G.R. Huxel (eds.). Food Webs at the Landscape Level. University of Chicago Press, Chicago.

Jefferies, R.L., Rockwell, R.F. \& K.F. Abraham, 2004b. The embarrassment of riches: agricultural food subsidies, high goose numbers, and loss of Arctic wetlands - a continuing saga. Environmental Reviews, 11: 193-232, National Research Council of Canada, Ottawa ON. Jefferies, R.L., Rockwell, R.F. \& K.F. Abraham, 2004c. Agricultural food subsidies, migratory connectivity and large-scale disturbance in arctic coastal systems: a case study. Integrative and Comparative Biology, 44: 130-139.

Kerbes, R.H., Kotanen P.M. \& R.L. Jefferies, 1990. Destruction of wetland habitats by lesser snow geese: a keystone species on the west coast of Hudson Bay. Journal of Applied Ecology, 27: 242258.

Kotanen, P.M. \& R.L. Jefferies, 1997. Long-term destruction of sub-arctic wetland vegetation by lesser snow geese. Écoscience, 4: 179-182.

Leafloor, J.O., Abraham, K.F., Rusch, D.H., Ross, R.K. \& M.R.J. Hill, 1996. Status of the Southern James Bay Population of Canada Geese. Pages 103 - 108 in J.T. Ratti (ed.). $7^{\text {th }}$ International 
P.C. O, P.M. Kotanen, and K.F. Abraham: Festuca survival and growth

Waterfowl Symposium, Memphis, Tennessee, 4-6 February 1996. Ducks Unlimited, Memphis, Tennessee.

Lindenmayer, D. \& M.A. McCarthy, 2002. Congruence between natural and human forest disturbance: a case study from Australian montane ash forests. Forest Ecology and Management, 155: 319-335.

McLaren, J.R. \& R.L. Jefferies, 2004. Initiation and maintenance of vegetation mosaics in an Arctic salt marsh. Journal of Ecology, 92: 648-660.

McNaughton, S.J., 1984. Grazing lawns: animals in herds, plant form, and coevolution. American Naturalist, 124: 863-886.

Miller, D.L., Smeins, F.E. \& J.W. Webb, 1998. Response of Texas Distichlis spicata coastal marsh following lesser snow goose herbivory. Aquatic Botany, 61: 301-307.

Mississippi and Atlantic Flyway Technical Sections. 2003. Management plan for the Southern James Bay Population of Canada Geese. Mississippi and Atlantic Flyway Councils.

Morgan, J.W. \& I.D. Lunt, 1999. Effects of time-since-fire on the tussock dynamics of a dominant grass (Themeda $\underline{\text { triandra })}$ in a temperate Australian grassland. Biological Conservation, 88: 379386.

Odion, D.C. \& F.W. Davis, 2000. Fire, soil heating, and the formation of vegetation patterns in chaparral. Ecological Monographs, 70: 149-469.

Pickett, S.T.A. \& P.S. White (editors), 1985. The ecology of natural disturbance and patch dynamics. Academic Press, Orlando, FL.

Rhoades, J.D., 1996. Salinity: electrical conductivity and total dissolved solids. Pages 417-435 in J. M. Bigham (ed.). Methods of Soil Analysis, Part 3 Chemical Methods. Soil Science Society of America and American Society of Agronomy, Madison, Wisconsin, USA. 
Rockwell, R.F., E.G. Cooch \& S. Brault, 1997. Dynamics of the mid-continent population of lesser snow geese - Projected impacts of reductions in survival and fertility on population growth rates. Pages 73-100 in B.D.J. Batt (ed.). Arctic Ecosystems in Peril: Report of the Arctic Goose Habitat Working Group. Arctic Goose Joint Venture. Canadian Wildlife Service and US Fish and Wildlife Service, Washington, D.C. (ISBN 0-9617279-3-4).

Shumway, S.W. \& M.D. Bertness, 1994. Patch size effects on marsh plant secondary succession mechanisms. Ecology, 75: 564-568.

Sousa, W.P., 1984. The role of disturbance in natural communities. Annual Review of Ecology and Systematics 15: 353-391.

Srivastava, D.S. \& R.L. Jefferies, 1996. A positive feedback: herbivory, plant growth, salinity, and the desertification of an arctic salt-marsh. Journal of Ecology, 84: 31-42.

Thomas, V. G. \& J. P. Prevett, 1982. The roles of the James and Hudson Bay Lowland in the annual cycle of geese. Le Naturaliste Canadien, 109: 913-925.

Urbanska, K.M. 1997. Safe-sites - interface of plant population ecology and restoration ecology. Pages 81-110 in K.M. Urbanska, N.R. Webb, and P.J. Edwards (eds.). Restoration Ecology and Sustainable Development. Cambridge University Press, Cambridge, U.K.

van der Wal, R., van de Koppel, J. \& M. Sagel, 1998. On the relation between herbivore foraging efficiency and plant standing crop: an experiment with barnacle geese. Oikos, 82: 123-130. 


\section{Figure Legends}

Fig. 1. Survival and biomass of transplanted Festuca in intact vegetation, naturally devegetated plots, and artificially grubbed plots in August 2001 and July 2002. Data are mean \pm SEM. a) Number of surviving transplants per plot, out of a total of 5 planted in June 2001. For each panel, letters above bars indicate results of post-hoc analyses (Bonferroni-corrected Mann-Whitney Utests); treatments sharing the same letter are not significantly different ( $p>0.05)$. Also shown is significance of a Kruskal-Wallis test comparing all three treatments. b) Live above-ground biomass and c) dead above-ground biomass per Festuca transplant; $n=20$, except as indicated. For each panel, letters above bars indicate results of post-hoc analyses (Tukey-Kramer tests); treatments sharing the same letter are not significantly different ( $p>0.05)$. Also shown is significance of an ANOVA comparing all three treatments. 


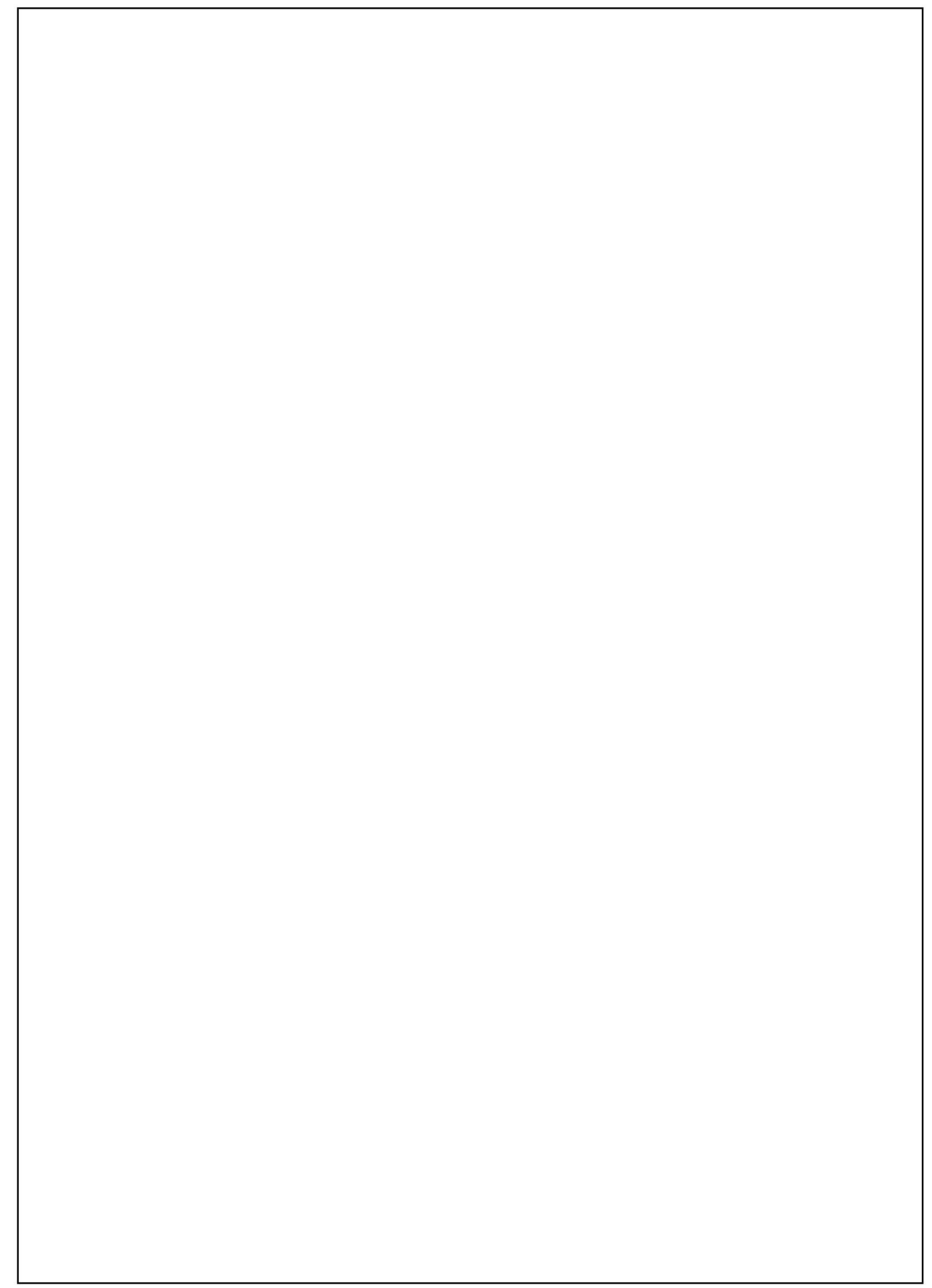

